\title{
A kutatás-fejlesztés és a versenyképesség térbeli összefüggései a visegrádi országokban
}

\section{The spatial interrelations of research and technological development and competitiveness in the Visegrad countries}

\author{
LENGYEL IMRE
}

\begin{abstract}
LENGYEL Imre: egyetemi tanár, Szegedi Tudományegyetem, Gazdaságtudományi Kar, Közgazdaságtani és Gazdaságfejlesztési Intézet; 6722 Szeged, Kálvária sgt. 1.; ilengyel@eco.u-szeged.hu
\end{abstract}

KULCSSZAVAK: megvalósult versenyképesség; kutatás-fejlesztés; endogén fejlődés

ABSZTRAKT: A regionális tudományban előtérbe került a térségek versenyképességének vizsgálata során a helyalapú, endogén területi fejlődés, amelyben kulcsszerep jut a kutatás-fejlesztésből származó eredmények helyi alkalmazásának. A megújult EU-s kohéziós politikának is egyik legfontosabb eszköze a kutatás-fejlesztést végző intézmények decentralizációja és a tudományos tevékenységek kiemelt támogatása, amely szempontok a regionális intelligens szakosodási (RIS3) stratégiákban is a figyelem középpontjában állnak. Tanulmányunkban a négy visegrádi ország (Csehország, Lengyelország, Magyarország, Szlovákia) 93 NUTS 3-as szintű területi egységének (megyéjének) versenyképességét vizsgáljuk, egy empirikus adatbázist elemezve többváltozós statisztikai módszerek segítségével. Az elemzéshez az endogén növekedési és fejlődési elméletek alapján megújított piramismodellt alkalmaztuk, a vizsgálatok eredményeként a megyék 4 típusát különítettük el. Horváth Gyula a témakörben jelentős kutatásokat végzett, az ő eredményeit is felhasználjuk Kelet-Közép-Európa térségei versenyképességi típusainak lehatárolásakor.

Imre LENGYEL: professor, Institute of Economics and Economic Development, Faculty of Economics and Business Administration, University of Szeged; Kálvária sgt. 1., H-6722 Szeged, Hungary; ilengyel@eco.u-szeged.hu

KEYWORDS: revealed competitiveness; research and development; endogenous development

ABSTRACT: In regional studies, place-based and endogenous regional development and regional competitiveness became a major focus accompanied by an emphasis on the local application of research and development. On a similar note, one of the most important means of the renewed EU cohesion policy is the institutional decentralization of research and development and the strengthened support of scientific activities, also acting as the central focus, for instance, for the regional innovation strategies for smart specialization (RIS3). In our study, first, we look at the definition of regional competitiveness and the related interpretation frames. Next, we focus on models of competitiveness and propose a renewed pyramid model of regional competitiveness as a synthesis

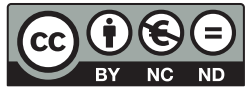


of the endogenous regional growth approach and development theories. Afterward, we proceed to the competitiveness analysis of 93 NUTS 3 level regions of 4 East-Central European countries (Czech Republic, Hungary, Poland, Slovakia) conducted by principal component analysis methods based on statistical data tables. We studied the spatial connection between research and development and county competitiveness along our renewed pyramid model. In all the four countries, we handled capital cities together with their neighboring counties as common standalone entities, and we also combined seven metropolitan counties in Poland. Echoing the widespread, relative definition of regional competitiveness, we mostly compared counties with each other. Based on our results, we differentiated four county competitiveness types. In determining the main competitiveness types of the Central and Eastern European regions we extensively drew upon the findings of Gyula Horváth, who carried out significant work in this field.

\section{Bevezetés}

Napjainkban a globalizációs folyamatok egyik következményeként a versenyképesség széles körben használt népszerü fogalommá vált, a versengésre való hajlamot, készséget fejezi ki, a versenyben való pozíciószerzés és tartós helytállás képességét, amit elsősorban a (valamilyen módon mért) sikeresség és az arra való képesség mutat. A versenyképesség értelmezése a vállalatok, iparágak közötti versenytől a várostérségek, régiók és országok közötti rivalizálásáig terjed (Chikán, Czakó 2009; Horváth 2009; Szerb 2010; Szirmai 2009; Török 2007). Szerteágazó elméleti és gazdaságpolitikai háttere miatt a versenyképesség fogalmára, értelmezésére a regionális tudományban is sokféle felfogás alakult ki (Barkley 2008; Bristow 2010; Camagni 2002; Gardiner, Martin, Tyler 2004; Huggins, Izushi, Thompson 2013).

Széles körben elfogadottá vált Storper $(1997,20$.) javaslata, aki szerint a regionális, városi versenyképesség: „egy (város)gazdaság képessége odavonzani és megtartani bizonyos tevékenységekben stabil vagy növekvő piaci részesedésü cégeket, miközben fennmarad vagy növekszik azok életszínvonala, akik részt vesznek bennük". Közismert a versenyképesség egységes fogalma (EC 1999, 75.; Lengyel 2000, 974.): ,a vállalatok, iparágak, régiók, nemzetek és nemzetek feletti régiók képessége relatíve magas jövedelem és relatíve magas foglalkoztatottsági szint tartós létrehozására, miközben a külgazdasági (globális) versenynek ki vannak téve". Ezen felfogás szerint a megtermelt tényezőjövedelmek (tőkeés munkajövedelmek) mellett, amelyek a gazdasági növekedéssel állnak kapcsolatban, a foglalkoztatás is fontos mércéje a térségek versenyképességének. Ez a szemlélet jelent meg az EU második kohéziós jelentésében (EC 2001, 37.), ahol a régiók versenyképessége „magas és növekvo életszínvonalat és magas foglalkoztatási rátát jelent egy fenntartható bázison". Az Európai versenyképességi jelentések is átveszik ezt a megközelítést (EC 2008, 15.): versenyképesség „egy nemzet vagy régió életszínvonalának fenntartható növekedését jelenti a nem önkéntes munkanélküliség lehető legalacsonyabb szintjén".

A versenyképességről és méréséről folyó vita új színezetet nyert a 2008-as válságot követően, amikor a gazdasági növekedés egyoldalú felfogását, a GDP túl- 
hangsúlyozását bírálva a társadalmi haladás, illetve jólét (welfare) és jóllét (well-being) fogalma került előtérbe (Aiginger, Firgo 2015; Siglitz, Sen, Fitousssi 2010). Már az ezredfordulót követően megjelentek a szemléletváltozás jelei, Meyer-Stamer (2008) bevezette a "rendszerszemléletü versenyképesség” (systemic competitiveness) fogalmát, a gazdaságban és társadalomban négy szintet megkülönböztetve, amelyek komplex rendszert alkotnak: mikroszint, mezoszint (regionális), makroszint és metaszint. Szerinte „egy térség (rendszerszemléletü) versenyképességét úgy definiálhatjuk, mint egy területi egység vagy régió képességét magas és növekvő jövedelem létrehozására és az ott élő emberek megélhetésének (livelihoods) javítására" (Meyer-Stamer 2008, 8.). Aiginger (2006) a versenyképességet úgy határozza meg, mint „egy ország vagy térség képességét a jólét létrehozására”. Az európai regionális versenyképességi index kidolgozása során Annoni és Dijkstra $(2013,4$.) javaslata is ezt a komplex felfogást tükrözi: „az a képesség, amely vonzó és fenntartható környezetet nyújt a vállalatoknak és a helybeli lakosoknak ott élni és dolgozni”. Az IMD versenyképességi jelentésében is megújult a versenyképesség fogalma (IMD 2016, 2.): „amely meghatározza, hogy hogyan képesek kezelni az országok, régiók és a vállalatok képességeikre alapozva a hosszú távú növekedést, munkahelyek létrehozását és a jólét javítását".

A gazdasági növekedés és fejlődés magyarázataiban egyre inkább az endogén jellegű értelmezések kerülnek előtérbe, a tudásbázis, a kutatás-fejlesztés, az innovációs milio, a klaszterek és hálózatok, a humán tőke, a bizalom stb. (Capello 2015; Fischer, Nijkamp 2014; Lengyel B. 2012; Lux 2013; Varga 2009). A városok és kistérségek versenyképességével, fejlődésével foglalkozó hazai vizsgálatok is felvetik az egyedi tényezők jelentőségét, több esetben összhangban a területi tőke szemléletével (Fábián, Tóth 2013; Jóna 2013; Koltai 2014; Kovács, Bodnár 2016; Papp 2012; Pénzes 2014; Rechnitzer 2016; Szirmai 2009; Vida 2016). A regionális versenyképesség elemzésében is e jelenlegi és jövőbeli endogén tényezők értékelődnek fel, különösen a kutatás-fejlesztés és decentralizációja, amely Kelet-Közép-Európában az egyik legfontosabb területfejlesztési eszköz lehetne (Horváth 2013).

Az endogén tényezők, más összefüggésben a területi tőke jellemzői régiótípusonként nagyon eltérőek (Camagni 2002; G. Fekete 2008; Káposzta, Nagy 2008; Rechnitzer 2016; Tóth 2013). Porter (1990) a kompetitív előnyök alapján az országok (és régiók) fejlődésének három egymást követő típusát különíti el: tényezővezérelt gazdaság (factor-driven, kevésbé fejlett régiók), beruházás (másképpen hatékonyság) -vezérelt gazdaság (investment- or efficiency-driven, közepes fejlettségü régiók) és innovációvezérelt gazdaság (innovation-driven, fejlett régiók). A regionális specializációval foglalkozó szakirodalomban néhány éve megjelent az evolúciós gazdaságföldrajz eredményein alapuló intelligens szakosodás (smart specialisation) koncepciója, amely az EU 2014 és 2020 közötti regionális politikájának alapja (EC 2012; Foray 2015; McCann 2015; OECD 2013; Thissen, Van Oort, Diodato, Ruijs 2013). E gondolatkör alapján elkülöníthető a régiók három ideáltípusa (EC 2012, 47.): tudásrégiók (knowledge region), ipari 
termelési zónák (industrial production zone) és nem a tudomány vagy a technológia által vezérelt régiók (non S\&T-driven region). A kutatás-fejlesztés fóleg a tudásrégiókban tud hozzájárulni a versenyképesség javulásához, emiatt a tudományos intézményekért, kutatási forrásokért folyó verseny igen erőteljes e térségek körében (Török, Borsi, Telcs 2005).

A szakirodalmi áttekintésből leszürhető, hogy napjainkban a versenyképesség fogalma meghaladja a gazdasági növekedés szokásos értelmezését, és beépült a társadalmi haladás és a fenntartható fejlődés néhány fontosabb endogén jellemzője. De továbbra is közgazdasági szempontú maradt, mivel a teljesítményalapú globális versenyben való tartós helytállásról van szó. A regionális versenyképesség újabb értelmezése: olyan helyalapú gazdasági növekedés, amely egyaránt származik a munkatermelékenység javulásából és a foglalkoztatás magas szintjéből, és amely növekedés hozzájárul a régió lakosai jólétének, életszínvonalának javulásához.

A regionális versenyképesség olyan duális koncepció, amely „magyarázza a régiók közötti gazdasági fejlettségben megfigyelhető relatív különbségeket, illetve próbálja megérteni a régiók jövőbeli gazdasági növekedési lehetőségeit" (Huggins, Izushi, Prokop, Thompson 2014, 28.). Az eddig elért eredmények (ex post szemlélet) mellett a további sikerekre való „képesség” is fontos (ex ante megközelítés). A relatív különbségek elemzésekor a térségeket lehet önmaguk korábbi helyzetéhez, de lehet a többi térséghez is viszonyítani.

A tanulmányban először bemutatjuk a vizsgálatunk során alkalmazott, endogén alapokon álló, megújult piramismodellt és regionális versenyképességi függvényt. Ezt követően a visegrádi országok megyéinek versenyképessége és kutatás-fejlesztése közötti kapcsolatot vizsgáljuk, többváltozós statisztikai módszereket alkalmazva, a 2012-2013-as évek adatai alapján.

\section{Megújult piramismodell}

A régiók versenyképességének vizsgálatára több modellt dolgoztak ki, amelyek egyike a piramismodell (Gardiner, Martin, Tyler 2004; Komlósi, Fujii 2012; Lengyel 2000, 2010; Lukovics 2008; Lukovics, Kovács 2008; Thissen et al. 2013). Ez az egymásra épülő logikai keret az input $\rightarrow$ output $\rightarrow$ eredmény (outcomes) felépítésnek felel meg (Huggins, Thompson 2013), lényegében megegyezik az alap $\rightarrow$ eszköz $\rightarrow$ cél Porter-féle (Competitiveness \& economic development, é.n.) gazdaságfejlesztési logikával is (Porter 2007). A korábbi piramismodell az egységes versenyképesség fogalmán alapult, amelynek a relatíve magas jövedelem (amit az egy före jutó GDP-vel mérünk) és a relatíve magas foglalkoztatottsági szint (amit a foglalkoztatottsági ráta mutat) a két fő tényezője. A gazdasági kibocsátás mérését (GDP/lakos) visszavezetjük a három közgazdaságtani kategória - a munkatermelékenység, a foglalkoztatási ráta és a munkaképes korúak - arányának szorzatára (Nemes Nagy 2006). 
Az újrafogalmazott piramismodell egyaránt épít az endogén regionális növekedés és fejlődés újabb irányzataira. A regionális növekedéselméleteknél alapul vett szokásos termelési tényezők az eredeti modellben is megjelentek (Lengyel 2000, 979.): a tőke (a modellben a külföldi befektetések), a munka (a modellben infrastruktúra és humán tőke), a technológia (a modellben a kutatás-fejlesztés). De az endogén fejlődéselméletekben megfogalmazódó stratégiai irányitás és intézmények, illetve az aktualizált gazdasági bázismodellben fontos agglomerációs elönyök (traded szektor és klaszterek) is bekerültek a piramismodellben szereplö új alaptényezők (mozgatóerők, inputs-1) közé (1.ábra).

Egy régió, térség versenyképessége mérésének és javításának négy egymásra épülő szintje az endogén növekedési és fejlődési elméletek alapján megújult piramismodellben a következő.

- Cél (outcomes): a régióban élők jólétének (welfare), életszínvonalának javulása.

- Megvalósult versenyképesség (output, a korábbi alapkategóriák): a versenyképesség mérését lehetővé tevő (jövedelem, munkatermelékenység és foglalkoztatottság) mutatók.

- Mozgatóerók (inputs-1, a korábbi alaptényezők): a megvalósult versenyképességet közvetlenül meghatározó gazdasági tényezők, amelyekre regionális gazdaságfejlesztési programok dolgozhatók ki, ezáltal javulhat a régió versenyképessége és felgyorsittható fejlődése.

1. ábra: A regionális versenyképesség megújult piramismodellje The renewed pyramid model of regional competitiveness

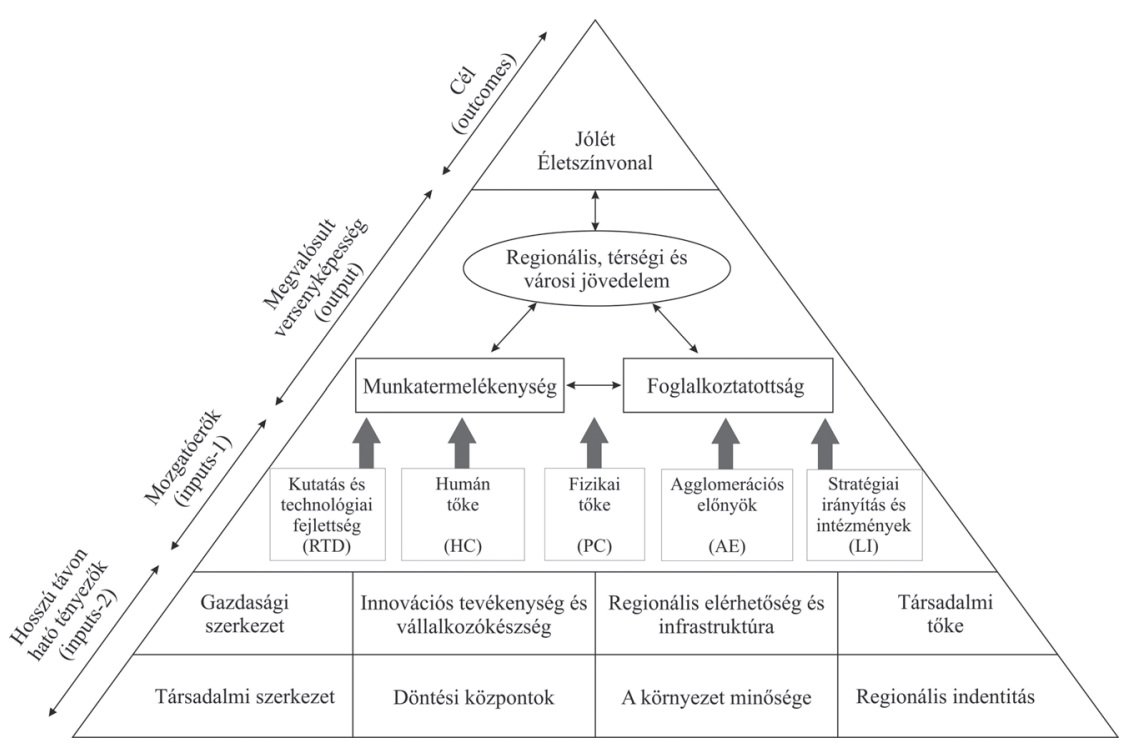

Forrás: a szerző saját szerkesztése. 
- Hosszú távon ható tényezők (inputs-2, korábban sikerességi faktorok): a megvalósult versenyképességet és mozgatóerőket közvetve, áttételesen befolyásoló, elsősorban gazdaságon kívüli tényezők, amelyek hosszabb időszakon keresztül módosulnak és főleg a területfejlesztési politika képes befolyást gyakorolni rájuk.

A piramismodell eredeti változatához képest nemcsak a szintek és a korábbi alaptényezők elnevezése és összetétele változott, hanem a hosszú távon ható tényezők, a „sikerességi faktorok” köre is. Az eredeti modellben szereplő „kis- és középvállalkozások” - mint vállalkozókészség - átkerültek a hosszú távú tényezők közé, összevonva az innovációs tevékenységekkel. Szintén idekerült az infrastruktúra, a regionális elérhetőség kiegészítéseként, továbbá a társadalmi tőke is hosszú távon ható tényezővé vált stb. A modell teljes körű átdolgozására jelen tanulmányban nem térünk ki.

A regionális növekedési elméletekhez hasonlóan a jólét (és életszínvonal) vagy a megvalósult versenyképesség és a mozgatóerők (inputs-1) közötti összefüggések vizsgálatára felírható a regionális versenyképességi függvény (RCF: Regional Competitiveness Function):

$$
\mathrm{RCF}=\mathrm{f}(\mathrm{RTD}, \mathrm{HC}, \mathrm{PC}, \mathrm{AE}, \mathrm{LI}) \text {, ahol }
$$

RTD = kutatási és technológiai fejlettség; $H C$ = humán tőke; $P C$ = fizikai tőke; $\mathrm{AE}=$ agglomerációs előnyök; $\mathrm{LI}$ = stratégiai irányítás és intézmények.

Az RCF lényegében a jólét (életszínvonal) vagy a megvalósult versenyképesség (output) és a rá ható mozgatóerők (inputs-1) közötti kapcsolatokat fejezi ki, a hagyományos regionális gazdasági növekedés gondolatait kiegészítve az endogén fejlődés újabb meglátásaival (Lengyel 2012, 2017; Lengyel, Rechnitzer 2013a, 2013b; Lengyel, Szakálné Kanó 2012). A visegrádi országok megyéire vonatkozó empirikus vizsgálatunkban a megújult piramismodellt alkalmazzuk, amelyben a kutatás-fejlesztés mint kutatás és technológiai fejlettség fontos szerepet tölt be.

\section{Empirikus eredmények}

Az Európai Unióban a térségek versenyképességének összehasonlító vizsgálatakor célszerü a NUTS-rendszerből kiindulni, mivel ezen alapuló, összevethetö, ellenőrzött adatbázisok is rendelkezésre állnak (Annoni, Dijkstra 2013; Filep 2007; Lengyel, Rechnitzer 2013b; Rechnitzer, Smahó 2011; Thissen, Van Oort, Diodato, Ruijs 2013). A piramismodell egyik fontos mutatója az egy lakosra jutó GDP, amelyet NUTS 3-as (megyei) szintnél kisebb területi egységekre nem érdemes megbecsülni, ezért tanulmányunkban a négy visegrádi ország megyéinek versenyképességét elemezzük.

Mind a négy országban a fővárosok formailag különálló megyét alkotnak, amelyeket ebben a vizsgálatban együtt kezelünk az agglomerációjukat alkotó 
megyékkel, mivel gazdasági szempontból nagyjából összefüggő térséget alkotnak. Pl. Budapesten és vonzáskörzetében, a településegyüttesben él a Közép-magyarországi régió lakosságának 86\%-a (Tóth 2014). Lengyelországban a fóvároson kívül további 7 nagyvárost vontunk össze a vonzáskörzetüket alkotó szomszédos megyékkel (Nowicki 2012). A négy országban összesen 11 nagyvárosi térséget alakítottunk ki, amelyek közül tíznek a lakónépessége legalább 1 millió fö (egyedül a Szczecin központú térségé kisebb). A négy országban összesen 93 területi egységet vizsgáltunk, amelyek átlagos lakosságszáma 690 ezer fö, a legkisebb megye 200 ezer fős, míg a legnagyobb 3280 ezer fős. A vizsgált területi egységek:

- Csehországban 13 megye (együtt: Praha+Středočeský),

- Lengyelországban 54 megye (együtt: Miasto Warszawa+Warszawskiwschodni+Warszawski-zachodni; Miasto Łódź+Lódzki; Miasto Kraków+Krakowski; Katowicki+Bytomski+Gliwicki+Sosnowiecki+Tyski; Miasto Poznań+Poznański; Miasto Szczecin+Szczeciński; Miasto Wrocław+Wrocławski;Trójmiejski+Gdański)

- Magyarországon 19 megye (együtt: Budapest+Pest),

- Szlovákiában 7 megye (együtt: Bratislavský+Trnavský).

A piramismodell mindegyik elemét több indikátorral mérjük, jelen vizsgálatban a jólét, a megvalósult versenyképesség és a mozgatóerők (inputs-1) kapcsolatát elemezzük (1. táblázat). A mozgatóerőknél mindegyik országra megegyező tartalmú mutatókat csak 4 elemnél tudtunk felhasználni, ezért a stratégiai irányítás és intézmények (LI) elemmel nem foglalkozunk jelen módszertani kísérletünkben. A megyék versenyképességét egymáshoz viszonyítjuk a 2012-2013-as évek keresztmetszeti adatai alapján.

A piramismodell mindegyik elemére egy-egy közös mutatót, sorrendet szeretnénk felhasználni, ezért az összetartozó indikátorokat valamilyen módon össze kell vonnunk. Többféle módszerrel valósítható meg a mutatókban lévő információk sürítése egyetlen mutatóba: kompozitmódszerrel (Huggins, Izushi, Prokop, Thompson 2014), rangsormódszerekkel, mint az IMD (2016) országok versenyképességére kidolgozott módszerében, vagy eltérő súlyozásokkal (Annoni, Dijkstra 2013) stb. Mi a fókomponens-elemzést választottuk, amely a különböző indikátorok információtartalmát új látens változókba, faktorokba süríti (Dusek, Kotosz 2016; Lengyel, Szakálné Kanó 2012). Ennek a módszernek egyik hátránya, hogy több faktor is létrejöhet, nem csak egyetlen.

Az 1. táblázat összes mutatócsoportjára főkomponens-analízist alkalmaztunk, amelynek eredményeként a piramismodell mindegyik vizsgált elemére egy-egy faktort kaptunk (a fizikai tőkét egyetlen mutató alkotja), amelyek elfogadható szinten sürítették az információkat (2. táblázat).

A jólétet három mutatóval fejeztük ki (1. táblázat), a számítások alapján adódó faktor komponenseinél az egy lakosra jutó rendelkezésre álló jövedelem (DI 0,83) és a vásárlóerő-paritáson számolt egy lakosra jutó GDP $($ GP 0,94$)$ a faktorral együtt mozog, míg a munkanélküliségi ráta (UR -0,67) fordított irányban, ami nem meglepő. A megvalósult versenyképességet (output) szintén három mutatóval mértük, a kommunalitások mindegyike egy irányba mutat (LP 0,85; ER 0,75; GA 0,98). 
1. táblázat: Az empirikus vizsgálat mutatói Indicators of empirical analysis

\begin{tabular}{|c|c|}
\hline Megnevezés & Indikátorok és az adatok forrásai \\
\hline \multicolumn{2}{|r|}{ Jólét } \\
\hline $\begin{array}{l}\text { Egy lakosra jutó rendelkezésre álló } \\
\text { jövedelem (DI) }\end{array}$ & $\begin{array}{l}\text { Real adjusted gross disposable income of households per } \\
\text { capita (recalculated by wages of counties), PPS, } 2013\end{array}$ \\
\hline Munkanélküliségi ráta (UR) & Registered unemployment rate of age group 15-64, \%, 2013 \\
\hline $\begin{array}{l}\text { Egy lakosra jutó GDP vásárlóerő- } \\
\text { paritáson(GP) }\end{array}$ & $\begin{array}{l}\text { GDP at current market prices by NUTS } 3 \text { regions } \\
\text { [nama_10r_3gdp], recalculated by PPS, 2012, and population } \\
\text { on } 1 \text { January by broad age group, sex and NUTS } 3 \text { region } \\
\text { [demo_r_pjanaggr3], } 2012\end{array}$ \\
\hline \multicolumn{2}{|r|}{ Megvalósult versenyképesség } \\
\hline Munkatermelékenység (LP) & $\begin{array}{l}\text { Gross domestic product (GDP) at current market prices by } \\
\text { NUTS } 3 \text { regions [nama_10r_3gdp], millio euro, 2012, and } \\
\text { employed persons, } 2012\end{array}$ \\
\hline Foglalkoztatási ráta (ER) & Employment rate of age group 15-64, \%, 2013 \\
\hline $\begin{array}{l}\text { Egy lakosra jutó bruttó hozzáadott } \\
\text { érték folyóáron (GA) }\end{array}$ & $\begin{array}{l}\text { Gross value added at basic prices by NUTS } 3 \text { regions } \\
\text { [nama_10r_3gva], 2012, millio euro, and population on } 1 \\
\text { January by broad age group, sex and NUTS } 3 \text { region } \\
\text { [demo_r_pjanaggr3], 2012 }\end{array}$ \\
\hline \multicolumn{2}{|r|}{ Mozgatóerók (inputs-1) } \\
\hline \multicolumn{2}{|l|}{ Kutatás és technológiai fejlettség, RTD } \\
\hline Szabadalmak & $\begin{array}{l}\text { Patent applications to the EPO by priority year by NUTS } 3 \\
\text { regions [pat_ep_rtot], 2010+2011+ } 2012 \text { per } 100 \text { thousands } \\
\text { persons }\end{array}$ \\
\hline Kutatók & Percentage of employed persons, \%, 2013 \\
\hline \multicolumn{2}{|l|}{ Humán tóke, HC } \\
\hline Hallgatók a felsőoktatásban & $\begin{array}{l}\text { Students of higher education institutes, full-time, per } \\
\text { thousand population, } 2013\end{array}$ \\
\hline Felsőoktatási végzettségűek & $\begin{array}{l}\text { Population by educational attainment (according to the LFSS), } \\
15+\text { years, } \%, 2013\end{array}$ \\
\hline \multicolumn{2}{|l|}{ Fizikai töke, PC } \\
\hline Bruttó állóeszköz & $\begin{array}{l}\text { Gross fixed capital formation (GFCF, formerly gross domestic } \\
\text { fixed investment), } 2010+2011+2012 \text { in percent of GDP, } \%\end{array}$ \\
\hline \multicolumn{2}{|l|}{ Agglomerációs elönyök, $A E$} \\
\hline Népsürüség & Population density, persons $/ \mathrm{km}^{2}, 2013$ \\
\hline Városi lakosság aránya & Share of town population, $\%, 2013$ \\
\hline $\begin{array}{l}\text { Egy lakosra jutó bruttó hozzáadott } \\
\text { érték vásárlóero"-paritáson }\end{array}$ & $\begin{array}{l}\text { Gross value added at basic prices by NUTS } 3 \text { regions } \\
\text { [nama_10r_3gva], 2012, recalculated by PPS, and population } \\
\text { on } 1 \text { January by broad age group, sex and NUTS } 3 \text { region } \\
\text { [demo_r_pjanaggr3], } 2012\end{array}$ \\
\hline
\end{tabular}

Forrás: Eurostat és a vizsgált országok statisztikai hivatalainak adatbázisai. 
2. táblázat: A főkomponens-elemzésből származó faktorok Factors of principal component analysis

\begin{tabular}{lcc}
\hline A faktor megnevezése & A faktor információtartalma & KMO-teszt \\
\hline Cél (outcomes) & 67,6 & 0,49 \\
Megvalósult versenyképesség (output) & 75,0 & 0,43 \\
Kutatás és technológiai fejlettség (RTD) & 79,0 & 0,51 \\
Humán tőke (HC) & 85,0 & 0,51 \\
Agglomerációs előnyök (AE) & 64,2 & 0,66 \\
\hline
\end{tabular}

Forrás: saját számítás.

A jóléti mutatók alapján számolt főkomponens statisztikai magyarázó erejénél az output alapján számolt megvalósult versenyképességi fókomponens erősebb, ezért ezt vettük alapul a további vizsgálatokhoz. A főkomponens (nulla várható értékủ és 1 szórású) értékei alapján felállítható a megyékhez rendelt megvalósult versenyképességi index (RC). Megjegyezzük, hogy a jólét és a megvalósult versenyképesség főkomponensei között szoros a kapcsolat (a lineáris korrelációs együttható: 0,912).

A megvalósult versenyképességi index alapján az első 12 régióból 8 nagyvárosi régió (2. ábra). A három fővárosi régió (Pozsony, Prága, Varsó) és Budapest térsége közé befért két lengyel megye (Legnicko-Głogowski, Poznań). A megvalósult versenyképesség és a térségek lakónépességének nagysága közötti kapcsolat szorossága csak közepes erősségü: $R^{2}=0,367$ (a lineáris korrelációs együttható $+0,61$ ).

A megvalósult versenyképességi index alapján a 93 megye között az első harmadban szerepel 6 magyar megye, ahogy említettük 6. Budapest (+Pest), 16. Győr-Moson-Sopron, 25. Komárom-Esztergom, 31. Vas és 32. Fejér megye. A lista vége felé 77. Borsod-Abaúj-Zemplén, 78. Békés, 84. Szabolcs-Szatmár-Bereg és 92. Nógrád megye.

A regionális versenyképességi függvény (RCF) a megvalósult versenyképesség (RC) mint függő változó és a mozgatóerők (inputs-1) mint magyarázó változók közötti kapcsolatokat fejezi ki. Többváltozós lineáris regressziót alkalmazva az alábbi összefüggés adódott (a heteroszkedaszticitási sztenderd hibák a második sorban zárójelben találhatók, a reziduális változók normális eloszlásúak, nem lép fel multikollinearitás):

$$
\mathrm{RC}_{\mathrm{i}}=+0,279 \mathrm{RTD}_{\mathrm{i}}-0,091 \mathrm{HC}_{\mathrm{i}}+0,193 \mathrm{PC}_{\mathrm{i}}+0,618 \mathrm{AE}_{\mathrm{i}}+\mathrm{e}_{\mathrm{i}}
$$

$$
(0,086) \quad(0,085) \quad(0,012) \quad(0,059)
$$

A többváltozós lineáris regressziós modell alapján a négy vizsgált ország megyéiben a megvalósult versenyképességet (RC) két input befolyásolja érdemben: az agglomerációs előnyök (AE) és a kutatási és technológiai fejlettség (RTD). A regressziószámítás azt mutatta, hogy az RC-t az agglomerációs előnyök (AE) aktívan befolyásolják $\left(\mathrm{R}^{2}=0,583\right.$ és a lineáris korrelációs együttható 0,76$)$, a népsűrűség és a városi lakosság aránya fontos tényezők (2. ábra). 
2. ábra: A megyék megvalósult versenyképességi indexe (RC) és lakónépességük nagysága (ezer fó) The revealed competitiveness index and population of counties (thousand persons)

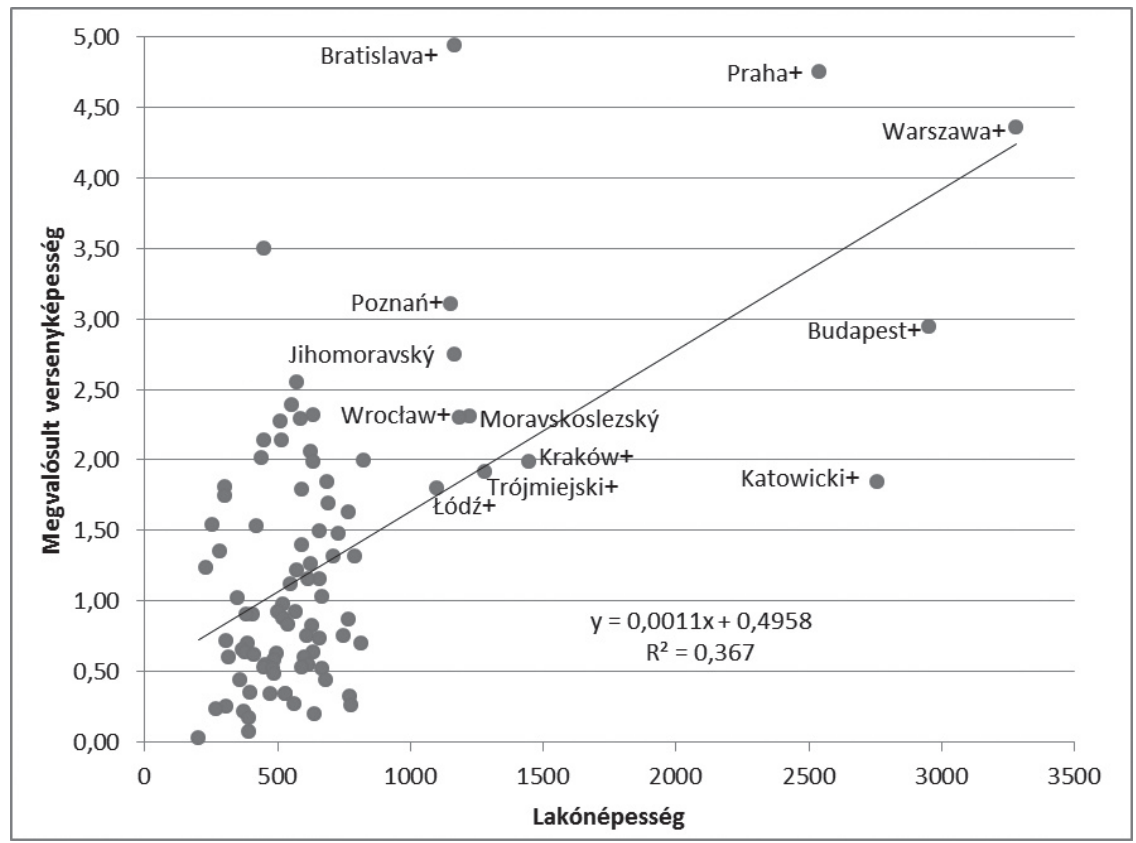

Megjegyzés: az ábrán a nagyvárosi térségeket nevesítettük, a megvalósult versenyképességi indexet átszámoltuk 0-5 intervallumra.

Forrás: a szerző saját számítása.

A regressziószámítás során a másik releváns magyarázó változó a kutatási és technológiai fejlettség (RTD) volt (3. ábra). Ebben az esetben kevésbé erős a megvalósult versenyképességi indexszel való kapcsolat $\left(R^{2}=0,4249\right.$ és a lineáris korrelációs együttható is közepes erősségü 0,65), mivel a gyengébb versenyképességü megyékben is előfordulnak szabadalmak és a kutatás-fejlesztésben is több foglalkoztatott található, valószínủleg a felsőoktatásban oktatók, kutatók miatt. De az is látható, hogy a versenyképesebb megyékben mindenütt erősebb a kutatási és technológiai fejlettség is.

A vizsgált 93 megye között a kutatás és technológiai fejlettségi index alapján 1. Budapest (+Pest), 9. Csongrád, 16. Hajdú-Bihar, 20. Baranya, 21. Veszprém, 24. Borsod-Abaúj-Zemplén és 29. Bács-Kiskun megye. De az utolsó 5 megyéből 4 magyar: 89. Jász-Nagykun-Szolnok, 90. Somogy, 91. Szabolcs-Szatmár-Bereg és 93. Nógrád megye. A kutatási és technológiai fejlettségi index szerinti területi különbségek Magyarországon a legnagyobbak a visegrádi országokon belül, ami abból is érzékelhető, hogy az első és utolsó területi egység is tőlünk került ki. 
3. ábra: A megvalósult versenyképességi index (RC) és a kutatási és technológiai

fejlettségi fökomponens (RTD)

Revealed competitiveness $(R C)$ and principal component of RTD

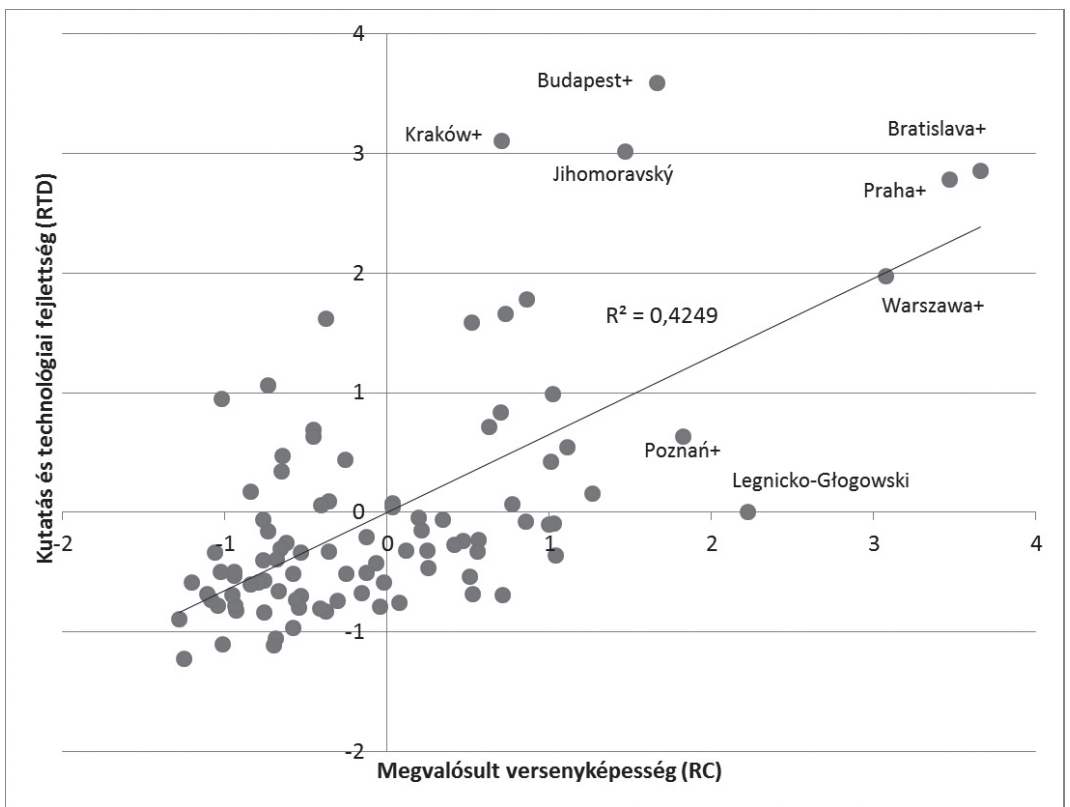

Forrás: a szerző saját számítása.

\section{A megyék típusai versenyképességük szerint}

A megvalósult versenyképességi index (RC) értékei szerint négy egyenlő osztályközt alakítottunk ki, amelyek alapján a megyéket négy csoportba, típusba soroltuk. A típusok értelmezéséhez felhasználjuk a kompetitív fejlődési fázisok fő jellemzőit és az intelligens szakosodás régiótípusait (3. táblázat):

a) Erős versenyképességü megyék: 14 ilyen megye különül el, a 8 cseh megye mellett a másik 3 fővárosi megye (köztük Budapest és térsége) és még két lengyel nagyvárosi térség. Ezek a térségek potenciális innovációvezérelt tudásrégiók: a jövedelmek jóval magasabbak a 4 ország átlagánál, az egy före jutó GDP közel másfélszeres, a foglalkoztatási ráta és a munkatermelékenység, a diplomások és kutatók aránya is magas, sokan tanulnak az egyetemeiken. Ezekben a régiókban alacsony a munkanélküliség, magas és növekvő a lakosság száma, magas a szolgáltatásokban és az iparban foglalkoztatottak aránya.

b) Közepes versenyképességü megyék (24 megye, köztük 5 cseh, 4 szlovák, 10 lengyel és 5 magyar megye: Győr-Moson-Sopron, Komárom-Esztergom, Vas, Fejér és Zala). A nagyvárosi térségekhez kapcsolódó, a német 
3. táblázat: A megyék versenyképességi típusainak főbb jellemzői Main indicators of counties by competitiveness types

\begin{tabular}{|c|c|c|c|c|c|c|}
\hline Mutatók & Mértékegység & Erös & Közepes & Gyenge & $\begin{array}{l}\text { Verseny- } \\
\text { képtelen }\end{array}$ & Együtt \\
\hline $\begin{array}{l}\text { Egy lakosra jutó rendelkezésre álló } \\
\text { jövedelem }\end{array}$ & ezer PPS, 2013 & 9,5 & 8,8 & 8,4 & 7,7 & 8,5 \\
\hline Egy lakosra jutó GDP & ezer PPS, 2012 & 24,4 & 17,6 & 13,5 & 11,1 & 15,6 \\
\hline Munkanélküliségi ráta & $\%, 2013$ & 8,2 & 11,0 & 13,9 & 18,1 & 13,4 \\
\hline Foglalkoztatási ráta & $\%, 2013$ & 68,8 & 60,8 & 54,0 & 50,0 & 57,0 \\
\hline Munkatermelékenység & ezer PPS, 2012 & 53,5 & 43,7 & 38,4 & 34,9 & 41,1 \\
\hline Lakónépesség & ezer lakos, 2013 & 1285,0 & 744,3 & 527,3 & 487,4 & 687,1 \\
\hline Lakónépesség változása & $\%, 2011 / 2001$ & 102,9 & 99,8 & 97,2 & 96,0 & 98,4 \\
\hline Szabadalmak, EPO, 100 ezer lakosra & $\mathrm{db}$ & 4,3 & 2,9 & 1,6 & 1,4 & 2,3 \\
\hline Kutatók a foglalkoztatottakon belül & $\%, 2013$ & 0,7 & 0,4 & 0,3 & 0,3 & 0,4 \\
\hline $\begin{array}{l}\text { Felsőoktatási végzettségűek a } \\
\text { lakosságon belül }\end{array}$ & $\%, 2013$ & 19,9 & 17,8 & 16,6 & 15,5 & 17,1 \\
\hline Hallgatók a felsőoktatásban & fó, ezer lakosra & 45,9 & 33,9 & 20,5 & 8,5 & 24,7 \\
\hline Mezőgazdasági foglalkoztatottak & $\%, 2013$ & 4,1 & 6,9 & 15,7 & 25,9 & 14,3 \\
\hline Iparban foglalkoztatottak & $\%, 2013$ & 33,8 & 34,3 & 30,0 & 25,3 & 30,5 \\
\hline Szolgáltatásokban foglalkoztatottak & $\%, 2013$ & 62,0 & 58,7 & 54,4 & 48,9 & 55,2 \\
\hline
\end{tabular}

Forrás: a szerző saját számítása.

és osztrák piacokhoz közeli megyék hatékonyságvezérelt, fóleg ipari térségek: a jövedelmek, a fajlagos GDP, a munkatermelékenység és a foglalkoztatási ráta, a szabadalmak száma, a diplomások és kutatók aránya csak kissé haladják meg a négy ország átlagát. A munkanélküliségi ráta magas, a megyék népessége átlagos és kissé fogy, igen magas az iparban foglalkoztatottak aránya.

c) Gyenge versenyképességü megyék (31 megye, köztük 2 szlovák, 20 lengyel és 9 magyar: Tolna, Veszprém, Csongrád, Bács-Kiskun, Hajdú-Bihar, Heves, Jász-Nagykun-Szolnok, Baranya és Somogy). Ezek a térségek a tényezővezéreltbool hatékonyságvezéreltbe váltó átmeneti térségek: a jövedelmek, a fajlagos GDP, a munkatermelékenység és a foglalkoztatási ráta, a szabadalmak száma, a diplomások és kutatók aránya kissé elmarad a négy ország átlagától. A munkanélküliségi ráta igen magas, a megyék népessége átlagos és nagy ütemben fogy, magas a mezőgazdaságban és az iparban foglalkoztatottak aránya

d) Versenyképtelen megyék (24 megye, köztük 20 lengyel és 4 magyar: BorsodAbaúj-Zemplén, Békés, Szabolcs-Szatmár-Bereg és Nógrád). Tényezővezérelt és nem a tudomány vagy a technológia által vezérelt (fóleg rurális) térségek: a jövedelmek, a fajlagos GDP, a munkatermelékenység és a foglalkoztatási ráta, a szabadalmak száma, a diplomások és kutatók aránya jelentősen elmarad a 4 ország átlagától. A munkanélküliségi ráta igen magas, a megyék népessége átlagos és rohamosan fogy, magas a mezőgazdaságban és az iparban foglalkoztatottak aránya. 
A kutatás-fejlesztés alapvető mutatói az erős versenyképességű megyékben kiemelkedők, mind a szabadalmak, mind a kutatók aránya magas. A gyenge és versenyképtelen térségekben a szabadalmak száma elenyésző, a kutatók aránya is jóval kisebb. Azaz továbbra is nagy területi egyenlötlenségek figyelhetők meg Kelet-Közép-Európában, amit Horváth Gyula (2009) is részletesen kifejtett. Mindez összhangban van a kompetitív fejlődéselmélet megállapításaival is, az innovációvezérelt térségekben lévő élenjáró vállalatoknak létigényük a $\mathrm{K}+\mathrm{F}$, míg a hatékonyságvezérelt térségekben lévő korai követő cégek, avagy a tényezővezérelt megyékben működő kései követők megveszik a piacon elérhető technológiákat, de önállóan nem fejlesztenek (Lengyel 2010).

A megyék versenyképesség szerinti szóródását tekintve a legnagyobb területi különbségek Magyarországon és Lengyelországban találhatók, ebben a két országban mind a négy típus fellelhető. Csehországban csak kétféle (erős és közepes), Szlovákiában pedig háromféle (nincs versenyképtelen) típusú megye létezik.

A megyék versenyképességi típusai térben is rendeződnek nyugat-keleti lejtő mentén (4. ábra). Megfigyelhető Csehországban egy összefüggő erős ver-

4. ábra: A megyék típusai a megvalósult versenyképességi index (RC) szerint Types of counties by revealed competitiveness index $(R C)$

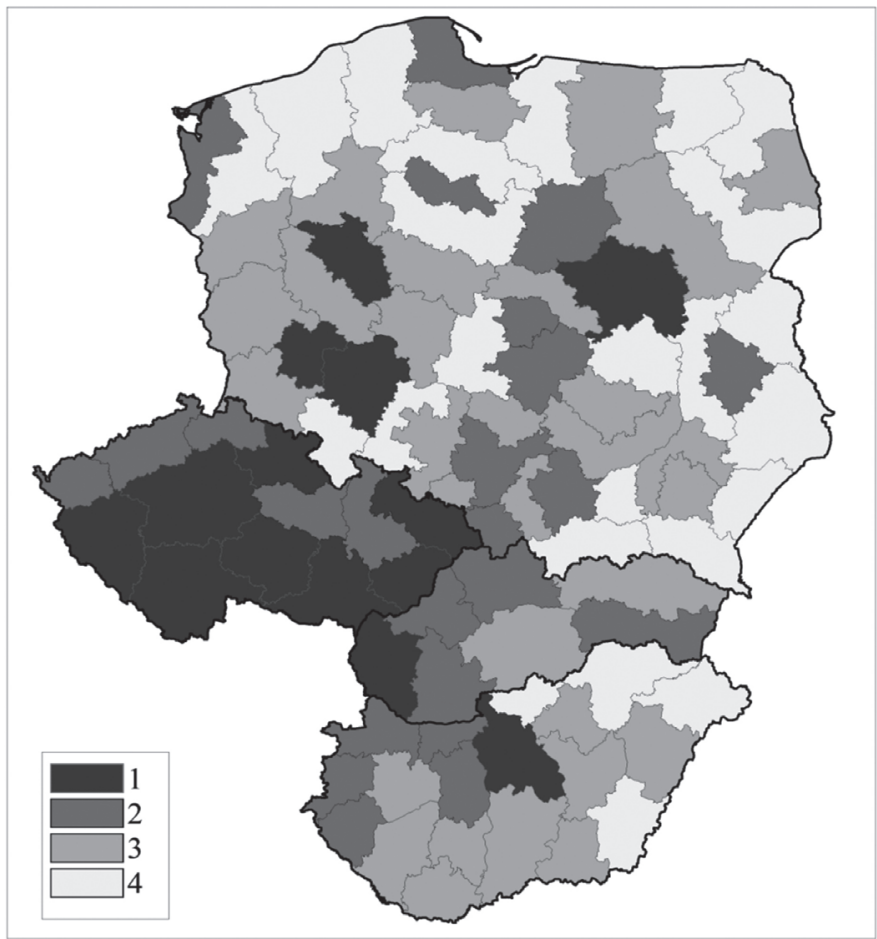

Jelmagyarázat: 1: erös; 2: közepes; 3: gyenge, 4: versenyképtelen. 
senyképességü térség, amelynek szomszédságában közepes versenyképességüek találhatók (pl. Szlovákiában), azaz erős szomszédsági hatás érvényesül. Lengyelországban inkább mozaikszerủen találhatók a versenyképesebb megyék, amelyek elsősorban a nagyvárosi térségek és vonzáskörzetük. Valószínűleg a gyorsan bővülő lengyel gazdaságban először a nagyvárosi növekedési pólusokban jelent meg versenyképes gazdaság, természetesen itt figyelembe kell vennünk az ország nagyságát, a jelentős távolságokat is. A versenyképtelen megyék az országok keleti határán, illetve Lengyelország északi részén helyezkednek el. A lengyel határ kivételével a másik három ország határán hasonló versenyképességü megyék találhatók.

\section{Összegzés}

A tanulmányban a regionális versenyképesség megújult piramismodellje alapján vizsgáltuk a négy visegrádi ország 93 NUTS 3-as területi szintü egységeinek, megyéinek egymáshoz viszonyított versenyképességét. A modell megújításakor kísérletet tettünk a regionális endogén növekedéselméletek újabb eredményeinek beépítésére.

Az empirikus vizsgálat során a modell elemeinek többségére sikerült releváns adatokat gyüjtenünk. A modell tesztelésekor az összetartozó mutatókból főkomponens-analízis segítségével képeztünk indexeket, amelyek közül az outputot kifejező megvalósult versenyképességi (RC) index eleget tesz a statisztikai elvárásoknak. Az RC-index és az inputok közötti kapcsolatot regionális versenyképességi függvénnyel fejeztük ki. Ezt a függvényt többváltozós regresszióelemzéssel teszteltük, így kimutatható vált, hogy a megvalósult versenyképességre az agglomerációs előnyök, valamint a kutatás és technológiai fejlettség fejt ki statisztikailag igazolható hatást.

A megvalósult versenyképesség alapján a megyék négy típusát különítettük el versenyképességük szerint: erős, közepes, gyenge és versenyképtelen megyék. A négy országot tekintve kirajzolódik a cseh megyékből és a közvetlen szomszédságukból álló versenyképes tömb, míg a lengyel és magyar térségek nagyon szóródnak. A kutatás-fejlesztés a visegrádi országokban is az erős versenyképességű megyékben tömörül, a nagyvárosi tudásrégiókban, főleg a fővárosokban, tovább növelve a területi egyenlőtlenségeket.

\section{Irodalom}

Aiginger, K. (2006): Competitiveness: From a dangerous obsession to a welfare creating ability with positive externalities. Journal of Industry, Competition and Trade, 2., 161-177. http://doi.org/cs64pp 
Aiginger, K., Firgo, M. (2015): Regional competitiveness under new perspectives. Austrian Institute of Economic Research, Vienna (Policy Paper; 26.)

Annoni, P., Dijkstra, L. (2013): European regional competitiveness index. Joint Research Centre, European Commission, Luxembourg

Barkley, D. L. (2008): Evaluations of regional competitiveness: Making a case for case studies. The Review of Regional Studies, 2., 212-243.

Bristow, G. (2010): Critical reflections on regional competitiveness. Routledge, London, New York

Camagni, R. (2002): On the concept of territorial competitiveness: Sound or misleading? Urban Studies, 13., 2395-2411. http://doi.org/c4kmcg

Capello, R. (2015): Regional economics. $2^{\text {nd }}$ ed. Routledge, London, New York

Chikán A., Czakó E. (szerk.) (2009): Versenyben a világgal. Vállalataink versenyképessége az új évezred küszöbén. Akadémiai Kiadó, Budapest

Competitiveness \& economic development (é.n.) http://www.isc.hbs.edu/competitiveness-economicdevelopment/Pages/default.aspx (Letöltés: 2016. november 8.)

Dusek T., Kotosz B. (2016): Területi statisztika. Akadémiai Kiadó, Budapest

EC (1999): Sixth periodic report on the social and economic situation and development of regions in the European Union. European Commission, Luxembourg

EC (2001): Second report on economic and social cohesion. European Commission, Brussels

EC (2008): European competitiveness report 2008. European Commission, Brussels

EC (2012): Guide to research and innovation strategies for smart specialisations (RIS 3). European Commission, Luxembourg

Fábián A., Tóth B. I. (2013): A kultúra területi mérhetősége és a kistérségek közművelődési jellemzöi. Tér és Társadalom, 1., 97-113.

Filep B. (2007): Competitiveness of Euroregions. In: Chodyńskiego, A. (ed.): Społeczne i ekologiczne aspekty zarządzania. Krakowska Szkoła Wyższa im. Andrzeja Frycza Modrzewskiego, Krakow, $25-32$.

Fischer, M., Nijkamp, P. (eds) (2014): Handbook of regional science. Springer, Heidelberg

Foray, D. (2015): Smart specialization: Opportunities and challenges for regional innovation policy. Routledge, London, New York

Gardiner, B., Martin, R., Tyler, P. (2004): Competitiveness, productivity and economic growth across the European regions. Regional Studies, 9., 1045-1068. http://doi.org/cb9bvw

G. Fekete É. 2008: A fejlődés és versenyképesség értelmezése kevésbé fejlett térségekben. In: Lengyel I., Lukovics M. (szerk.): Kérdőjelek a régiók gazdasági fejlődésében. SZTE Gazdaságtudományi Kar Közleményei, JATEPress, Szeged, 130-152.

Horváth Gy. (2009): Regionális versenyképesség Európában. In: Horváth Gy. (szerk.): Régiók és települések versenyképessége. MTA Regionális Kutatások Központja, Pécs, 84-105.

Horváth Gy. (2009): Regionális egyenlőtlenségek a kelet- és közép-európai kutatási térségben. Magyar Tudomány, 12., 1499-1512.

Horváth, Gy. (2013): The regional structure and decentralisation of science in Central and Eastern Europe. In: Pálné Kovács, I., Scott, J, Gál, Z. (eds): Territorial cohesion. For the 70th anniversary of the Transdanubian Research Institute. Institute for Regional Studies Centre for Economic and Regional Studies, Hungarian Academy of Sciences, Pécs, 196-207.

Huggins, R., Izushi, H., Prokop, D., Thompson, P. (2014): The global competitiveness of regions. Routledge, Abingdon, New York

Huggins, R., Izushi, H., Thompson, P. (2013): Regional competitiveness: Theories and methodologies for empirical analysis. Journal of CENTRUM Cathedra, 2., 155-172. http://doi.org/bssv

Huggins, R., Thompson, P. (2013): UK Competitiveness Index 2013. Centre for International Competitiveness, Cardiff

IMD (2016): The World Competitiveness Yearbook. IMD, Lausanne

Jóna Gy. (2013): A területi tőke fogalmi megközelítései. Tér és Társadalom, 1., 30-51.

Káposzta, J., Nagy, H. (2008): Gross domestic product as an indicator of regions' competitiveness for plant-soil interrelations. Cereal Research Communications, Supplement 5., 2039-2042.

Koltai Z. (2014): Sikeres és versenyképes városok. Piackutatás a magyar települések körében. PTE Felnőttképzési és Emberi erőforrás Kar, Pécs 
Komlósi, É., Fujii, T. (2012): Competitiveness of Japanese functional urban areas, (JFUAs): empirical testing of the pyramid model. Japanese Journal of Human Geography, 5., 54-71.

Kovács P., Bodnár G. (2016): Az endogén fejlődés értelmezése vidéki térségekben PLS-útelemzés segítségével. Statisztikai Szemle, 2., 143-161. http://doi.org/bssw

Lengyel B. (2012): Tudásalapú regionális fejlödés. L’Harmattan, Budapest

Lengyel I. (2000): A regionális versenyképességről. Közgazdasági Szemle, 12., 962-987.

Lengyel I. (2010): Regionális gazdaságfejlesztés. Versenyképesség, klaszterek és alulról szerveződő stratégiák. Akadémiai Kiadó, Budapest

Lengyel I. (2012): A kelet-közép-európai országok régióinak versenyképessége. In: Rechnitzer J., Smahó M. (szerk.): Jármüipar és regionális versenyképesség. Széchenyi István Egyetem UniversitasGyőr Nonprofit Kft., Győr, 191-229.

Lengyel, I. (2017): Competitive and uncompetitive regions in transition economies: the case of the Visegrad post-socialist countries. In: Huggins, R., Thompson, R. (eds.): Handbook of regions and competitiveness. Edward Elgar, Cheltenham (forthcoming)

Lengyel, I., Rechnitzer, J. (2013a): The competitiveness of regions in the Central European transition countries. The Macrotheme Review, 2., 106-121.

Lengyel, I., Rechnitzer, J. (2013b): Drivers of regional competitiveness in the Central European countries. Transition Studies Review, 3., 421-435. http://doi.org/bssx

Lengyel, I., Szakálné Kanó, I. (2012): Competitiveness of Hungarian urban microregions: Localization agglomeration economies and regional competitiveness function. Regional Statistics, 2., 27-44. http://doi.org/bssz

Lukovics M. (2008): Térségek versenyképességének mérése. JATEPress, Szeged

Lukovics M., Kovács P. (2008): Eljárás a területi versenyképesség mérésére. Területi Statisztika, 3., 245-263.

Lux G. 2013: Az ipari parkok a területi versenyképességben: telephelyek vagy fejlesztési csomópontok? In: Kiss É. (szerk.): A hazai ipari parkok különböző dimenzióban. Dialóg Campus Kiadó, Budapest, Pécs, 294-309.

McCann, P. (2015): The regional and urban policy of the European Union. Cohesion, results-orientation and smart specialisation. Edward Elgar, Cheltenham http://doi.org/bss2

Meyer-Stamer, J. (2008): Systemic competitiveness and local economic development. Mesopartner, Duisburg

Nemes Nagy J. (2006): A területi versenyképesség elemzési módszerei. In: Horváth Gy. (szerk.): Régiók és települések versenyképessége. MTA Regionális Kutatások Központja, Pécs, 69-83.

Nowicki, M. (ed.) (2012): The investment attractiveness of the regions and sub-regions of Poland. The Gdansk Institute for Market Economics, Gdansk

OECD (2013): Innovation-driven growth in regions: The role of smart specialisation (preliminary version). OECD, Paris

Papp Zs. (2012): A turisztikai desztinációk versenyképessége - hogyan mérjük? Modellek és módszerek áttekintése. In: Bajmócy Z., Lengyel I., Málovics Gy. (szerk.): Regionális innovációs képesség, versenyképesség és fenntarthatóság. JATEPress, Szeged, 225-238.

Pénzes, J. (2014): Competitiveness of Hungarian towns after the change of regime. Central European Regional Policy and Human Geography, 1., 49-61.

Porter, M. E. (1990): The competitive advantage of nations. The Free Press, New York http://doi.org/bss3

Porter, M. E. (2007): Competitiveness: implications for Central Europe and the Czech Republic. Paper presented in Prague, 22 October.

Rechnitzer J. (2016): A területi tőke a városfejlődésben - A Győr-kód. Dialóg Campus, Pécs

Rechnitzer J., Smahó M. (2011): Területi politika. Akadémiai Kiadó, Budapest

Stiglitz, J. E., Sen, A., Fitoussi, J. P. (szerk.) (2010): A Bizottság jelentése a gazdasági teljesítmény és a társadalmi fejlődés méréséről. Statisztikai Szemle, 3., 305-320.

Storper, M. (1997): The regional world. The Guilford Press, New York

Szerb L. (2010): A magyar mikro-, kis- és középvállalatok versenyképességének mérése és vizsgálata. Vezetéstudomány, 12., 20-35.

Szirmai V. (szerk.) (2009): A várostérségi versenyképesség társadalmi tényezői. Hogyan lehetnek a magyar nagyvárosok versenyképesebbek? Dialóg Campus Kiadó, Budapest, Pécs 
Thissen, M., Van Oort, F., Diodato, D., Ruijs, A. (2013): Regional competitiveness and smart specialization in Europe: Place-based development in international economic networks. Edward Elgar, Cheltenham http://doi.org/bss4

Tóth B. I. (2013): A hazai kistérségek vonzerejének és területi tőkéjének néhány összefüggése. Területi Statisztika, 1., 3-18.

Tóth G. (2014): Az agglomerációk, településegyüttesek lehatárolásának eredményei. Területi Statisztika, 3., 289-300.

Török Á. (2007): Verseny és szabályozás. A versenyképesség egyes jogi és szabályozási feltételei Magyarországon. Közgazdasági Szemle, 12., 1066-1084.

Török, Á., Borsi, B., Telcs, A. (2005): Competitiveness in research and development: Comparisons and performance. Edward Elgar, Cheltenham http://doi.org/bss5

Varga A. (2009): Térszerkezet és gazdasági növekedés. Akadémiai Kiadó, Budapest

Vida Gy. (2016): A vidéki agglomerációk, agglomerálódó térségek és nagyvárosi településegyüttesek versenyképességének sajátosságai. In: Lengyel I., Nagy B. (szerk.): Térségek versenyképessége, intelligens szakosodása és újraiparosodása. JATEPress, Szeged, 204-222. 